Erratum

\title{
Erratum: Ribeiro, M. H. L. et al. Lipoaminoacids Enzyme-Based Production and Application as Gene Delivery Vectors. Catalysts 2019, 9, 977
}

\author{
Maria H. L. Ribeiro ${ }^{1,2, *}$, Patricia Carvalho ${ }^{3}$, Tiago Santos Martins ${ }^{1}$ and Célia M. C. Faustino ${ }^{1,2}$ \\ 1 Faculty of Pharmacy, Universidade Lisboa, Av. Gama Pinto, 1649-003 Lisboa, Portugal; \\ tiagosantosmartins@hotmail.com (T.S.M.); cfaustino@ff.ul.pt (C.M.C.F.) \\ 2 Research Institute for Medicines (iMed.ULisboa), Faculty of Pharmacy, Universidade Lisboa, \\ Av. Gama Pinto, 1649-003 Lisboa, Portugal \\ 3 Instituto de Medicina Molecular, Faculdade de Medicina, Universidade de Lisboa, 1649-028 Lisbon, Portugal; \\ pcarvalho@campus.ul.pt or pcarvalho@medicina.ulisboa.pt \\ * Correspondence: mhribeiro@ff.ul.pt; Tel.: +351-21-7946400; Fax: +351-21-7946470
}

Received: 6 February 2020; Accepted: 7 February 2020; Published: 12 February 2020

check for updates

The authors wish to make the following erratum to this paper [1]:

The affiliation of Patricia Carvalho "DART Diagnostics, Tec Labs-Centro de Inovação, Campus da FCUL, 1749-016 Lisboa, Portugal" should be replaced with:

"Instituto de Medicina Molecular, Faculdade de Medicina, Universidade de Lisboa, 1649-028, Lisbon, Portugal".

The email address of Tiago Santos Martins tiago.santos@campus.ul.pt should be replaced with:

"tiagosantosmartins@hotmail.com"

This update does not change any of the scientific results of the paper. The authors would like to apologize for any inconvenience caused to the readers by these changes. The manuscript will be updated and the original will remain online on the article webpage: https://www.mdpi.com/2073-4344/9/12/977.

\section{Reference}

1. Ribeiro, M.H.L.; Carvalho, P.; Martins, T.S.; Faustino, C.M.C. Lipoaminoacids enzyme-based production and application as gene delivery Vectors. Catalysts 2019, 9, 977. [CrossRef]

(C) 2020 by the authors. Licensee MDPI, Basel, Switzerland. This article is an open access article distributed under the terms and conditions of the Creative Commons Attribution (CC BY) license (http://creativecommons.org/licenses/by/4.0/). 